\title{
MODEL PEMBELAJARAN PENCAPAIAN KONSEP DENGAN PENDEKATAN ILMIAH TERHADAP KEMAMPUAN REPRESENTATIF MAHASISWA PRODI PENDIDIKAN MATEMATIKA FKIP UHN
}

\author{
Adi Suarman Situmorang; Hardi Tambunan
}

\author{
Pendidikan Matematika FKIP Univ. HKBP Nommensen \\ adisuarmansitumorang@uhn.ac.id
}

\begin{abstract}
Absrak
Tujuan penelitian ini adalah untuk mengetahui persentase ketuntasan belajar kemampuan representatif mahasiswa prodi pendidikan matematika FKIP UHN yang diajarkan dengan desain model pembelajaran pencapaian konsep dengan pendekatan ilmiah. Hasil penelitian menunjukkan bahwa: 1) desain model pembelajaran pencapaian konsep dengan pendekatan ilmiah terhadap kemampuan representatif yang telah dirancang sudah sangat baik karena aktivitas mengajar dosen dari observer pada semua aspek dan indikator model adalah 4,55 dan aktivitas aktif mahasiswa dari hasil observasi adalah 4,51 yang artinya aktivitas aktif mahasiswa berada pada kategori "Sang Baik". 2) pencapaian ketuntasan kemampuan representatif mahasiswa prodi pendidikan matematika yang mengikuti matakuliah analisis riel 1 tahun akademik 2019/2020 telah tuntas secara klasikal karena 95 orang dari 110 orang atau sekita 86,36\% mahasiswa telah mencapai nilai ketuntasan minimal $\geq 75$.
\end{abstract} Abstract

Kata Kunci: Model Pencapaian Konsep, Pendekatan Ilmiah, Kemampuan Representatif

The purpose of this research was to determine the percentage of completeness learning of the representative ability of mathematics education study program students at FKIP UHN who are taught with the design of learning models to reach concepts using scientific means. The results showed that: 1) designthe concept of learning achievement model with a scientific approach to the representative ability that has been designed is very good because the teaching activity of the lecturer from the observer on all aspects and indicators of the model is 4.55 and the active activity of students from observations is 4.51 which means that the active activities of students are at the "The Good" category. 2) the achievement of the completeness of the representative ability of mathematics education study program students who took the first real academic year 2019/2020 academic course has been completed classically because 95 people out of 110 people or around $86.36 \%$ students have achieved a minimum mastery value of $\geq 75$.

Keywords: Concept Achievement Model, Scientific Approach, Representative Ability

\section{Pendahuluan}

Salah satu kegiatan pembelajaran yang dilaksanakan disekolah adalah pembelajaran matematika. Tujuan dari pembelajaran matematika adalah agar siswa memiliki kemampuan sebagai berikut: 1) Memahami konsep matematika, menjelaskan keterkaitan antar konsep dan mengaplikasikan konsep atau algoritma, secara luwes, akurat, efisien, dan tepat, dalam pemecahan masalah. 2) Menggunakan penalaran pada pola dan sifat, melakukan manipulasi matematika dalam membuat generalisasi, menyusun bukti, atau menjelaskan gagasan dan pernyataan matematika. 3) Memecahkan masalah yang meliputi kemampuan memahami masalah, merancang model matematika, menyelesaikan model dan menafsirkan solusi yang diperoleh. 4) Mengkomunikasikan gagasan dengan simbol,tabel, diagram, atau media lain untuk memperjelas keadaan atau masalah. 5) Memiliki sikap menghargai kegunaan matematika dalam kehidupan, yaitu memiliki rasa ingn tahu, perhatian, dan minat dalam mempelajari matematika, serta sikap ulet dan percaya diri dalam pemecahan masalah (Depdiknas, 2007).

Dari tujuan pembelajaran matematika diatas terlihat bahwa dalam unsur utama yang harus dimiliki oleh peserta didik dalam belajar matematika adalah pemahaman konsep yang baik 
dan benar. Oleh karena itu, pemahaman konsep matematika menjadi dasar pengetahuan terhadap tujuan pembelajaran dalam kurikulum sekolah (Mulligan \& Mitchelmore, 2009). Dilingkup sekolah, seorang siswa dapat peka terhadap matematika hanya jika mereka memahami konsep dan menginterpretasikannya.

Interpretasi diartikan sebagai representasi yang menjadi salah satu komponen utama dalam belajar matematika (NCTM, 2000: 67; Abrahamson, 2006), dikarenakan objek-objek matematika sebagian besar berupa ide-ide abstrak (Kaput, 1991). Sehingga untuk mengetahui seseorang memahami suatu konsep matematika apabila dapat menyatakan pengertian konsep dengan (representasi) bahasanya sendiri (Friska, 2018).

Kemampuan representasi adalah salah satu standar proses pembelajaran matematika yang perlu ditumbuhkan dan dimiliki siswa. Standar proses ini hendaknya disampaikan tidak secara terpisah dengan materi matematika. Sayang sekali, representasi sering diajarkan dan dipelajari seolah-olah berdiri sendiri tanpa ada kaitan dalam matematika (Depkdiknas, 2007:51).Padahal, dengan representasi diharapkan dapat menunjang pemahaman siswa terhadap konsep-konsep matematika dan hubungannya dalam mengkomunikasikan matematika, argumen, dan pemahaman seorang terhadap ide lainnya, dalam mengenal hubungan antar konsep-konsep matematika (NCTM, 2000: 206).

Representasi merupakan ungkapan dari suatu ide matematika yang ditampilkan peserta didik sebagai bentuk yang mewakili situasi masalah guna menemukan solusi dari masalah tersebut. Hal ini sesuai dengan pendapat Indah (2015) yang mengungkapkan bahwa representasi adalah ungkapan-ungkapan dari ide matematis yang ditampilkan siswa sebagai model atau bentuk pengganti dari suatu situasi masalah yang digunakan untuk menemukan solusi dari suatu masalah yang sedang dihadapinya sebagai hasil dari interpretasi pikirannya.

Kurangnya pemahaman siswa terhadap konsep matematika perlu diatasi dengan kemampuan siswa dalam merepresentasikan suatu konsep matematika yang dipelajari. Sehingga penggunaan beberapa representasi membantu siswa memahami konsep matematika (Dundar, 2015; Panasuk, 2011). Representasi memiliki peranan yang sangat penting dalam pembelajaran matematika dikarenakan siswa dapat mengembangkan dan memperdalam pemahaman akan konsep dan keterkaitan antarkonsep matematika yang mereka miliki melalui membuat, membandingkan, dan menggunakan representasi.

Kemampuan representasi matematis siswa dapat di ukur melalui beberapa indikator kemampuan representasi matematis. Indikator representasi matematis siswa menurut Hutagaol Kartini (2013: 20) adalah sebagai berikut: a) Representasi visual. b) persamaan atau ekspresi matematis. c) kata-kata atau teks tertulis.

Berdasarkan permasalahan diatas, maka model pembelajaran yang dianggap efektif untuk merangsang peserta didik dalam merepresentasikan kemampuan pemahaman konsep dalam belajar matematika adalah model pembelajaran pencapaian konsep dengan pendekatan ilmiah. Model pembelajaran pencapaian konsep adalah suatu model pembelajaran yang menekankan pada pemahaman konsep kepada siswa, dimana guru akan mengawali pengajarannya dengan menyajikan data atau contoh dan bukan contoh, kemudian guru akan meminta siswa untuk mengamati data atau contoh tersebut, dan siswa dibimbing agar mampu mengidentifikasi ciri-ciri/ karakteristik dari contoh yang diberikan (Situmorang Adi S., 2019).

Pada prinsipnya model pembelajaran pencapaian konsep adalah suatu bentuk mengajar yang menggunakan data untuk mengajarkan konsep kepada siswa. Model pencapaian konsep ini 
banyak menggunakan contoh dan non contoh. Ada tiga cara yang dapat dilakukan oleh guru dalam membimbing aktifitas siswa yaitu: (a) guru mendorong siswa untuk menyatakan pemikiran mereka dalam bentuk hipotesa, bukan dalam bentuk observasi; (b) guru menuntun jalan pikiran siswa ketika mereka menetapkan apakah suatu hipotesis diterima atau tidak; (c) guru meminta siswa untuk menjelaskan mengapa mereka menerima atau menolak suatu hipotesis (Nainggolan Sintong, 2015).

langkah-langkah model pembelajaran pencapaian konsep terdiri dari 3 tahap, yaitu: Tahap pertama melibatkan penyajian data pada pembelajar. Setiap unit data merupakan contoh dan noncontoh konsep yang terpisah. Para pelajar diberi tahu contoh positif memiliki satu gagasan umum; tugas mereka adalah mengembangkan satu hipotesis tentang sifat dari konsep tersebut. Para pelajar diminta untuk membandingkan dan memverifikasi sifat-sifat dari contoh-contoh yang berbeda itu yangselanjutnya diminta untuk menamai konsep-konsep mereka dan menyampaikan aturan-aturan atau definisi-definisi konsep menurut sifat-sifatnya yang paling esensial. Tahap Kedua, pada tahap ini siswa menguji penemuan konsep mereka, pertama-tama dengan mengidentifikasi secara tepat contoh-contoh tambahan yang tidak dilabeli dari konsep itu dan kemudian dengan membuat contoh-contoh mereka. Setelah itu, guru (dan siswa) dapat membenarkan atau tidak membenarkan hipotesis mereka, merevisi pilihan konsep atau sifat-sifat yang mereka tentukan sebagaimana mestinya. Tahap ketiga, pada ini, siswa mulai menganalisis strategi-strategi dengan segala hal yang mereka gunakan untuk mencapai konsep. Ada beberapa siswa yang pada mulanya mencoba konstruk-konstruk yang luas dan secara bertahap mempersempit konstruk-konstuk itu; ada pula yang memulai dengan konstruk-konstruk yang lebih berbeda (Joyce Bruce, 2009).

Selain dari pada itu dengan menggunakan pendekatan ilmiah maka pembelajaran akan lebih terarah dan menarik bagi siswa. Pendekatan ilmiah mengarahkan siswa dalam menghadapi fakta-fakta yang relevan dengan kehidupan sehari-hari. Didalam pendekatan ilmiah siswa akan melalui tahap-tahap pembelajaran seperti mengamati, mengumpulkan informasi, mengolah informasi, dan mengkomunikasikan, sehingga pendekatan ilmiah dapat mendorong siswa untuk mampu merepresentasikan kemampuan pemahaman konsepnya.

Pendekatan Ilmiah merupakan teknik merumuskan pertanyaan dan menjawab pertanyaan melalui kegiatan observasi, mencoba melaksanakan aktivitas, atau melaksanakan percobaan. Oleh karena itu, pada umumnya, pelaksanaan pendekatan ilmiah tersusun dalam tujuh langkah berikut: 1) Merumuskan pertanyaan, 2) Merumuskan latar belakang penelitian, 3) Merumuskan hipotesis, 4) Menguji hipotesis melalui percobaan, 5) Menganalisis hasil penelitian dan merumuskan kesimpulan, 6) Jika hipotesis terbukti benar maka daapt dilanjutkan dengan laporan, 7) Jika Hipotesis terbukti tidak benar atau benar sebagian maka lakukan pengujian kembali.

Pada ketujuh langkah kegiatan, pada dasarnya untuk mengembangkan keterampilan berpikir logis berdasarkan fakta dan teori.Pertanyaan yang muncul dari pengamatan pada hakekatnya untuk mendalami atau memperluas cakrawala ilmu. Oleh karena itu, dalam proses pendalam di sini mencakup aktivitas eksplorasi, elaborasi, dan konfirmasi untuk meyakinkan bahwa ilmu pengetahuan yang telah siswa ketahui teruji kebenarannya. Yang menarik di sini, bagaimana guru mengembangkan keterampilan siswa bertanya.Masalah ini perlu menjadi penekanan karena dalam pelaksanaan pembelajaran sebelumnya telah terbentuk kebiasaan guru yang bertanya dan siswa selalu menjawab. Dalam penerapan kurikulum 2013, siswa menggali informasi dengan diawali dengan mengamati dan bertanya, lalu siswa mendalami informasi untuk menjawab pertanyaan. Oleh karena itu, penguasaan 
teori dalam sebagai dasar untuk menerapkan pendekatan ilmiah perlu siswa kembangkan melalui proses pengamatan atau penelaahan. Berdasarkan teori yang diperolehnya maka siswa dapat menyederhanakan penjelasan tentang suatu gejala, memprediksi, memandu perumusan kerangka pemikiran untuk memahami masalah. Bersamaan dengan itu, teori menyediakan konsep yang relevan dengan materi pembahasan sehingga teori menjadi dasar dan mengarahkan perumusan pertanyaan penelitian.

Prinsip-Prinsip Kegiatan Pembelajaran dengan Pendekatan Saintifik Kurikulum 2013 yaitu sebagai berikut : 1) Peserta didik difasilitasi untuk mencari tahu, 2) Peserta didik belajar dari berbagai sumber belajar, 3) Proses pembelajaran menggunakan pendekatan ilmiah, 4) Pembelajaran berbasis kompetensi, 5) Pembelajaran terpadu, 6) Pembelajaran yang menekankan pada jawaban divergen yang memiliki kebenaran multi dimensi, 7) Pembelajaran berbasis keterampilan aplikatif, 8) Peningkatan keseimbangan, kesinambungan, dan keterkaitan antara hard-skills dan soft-skills, 9) Pembelajaran yang mengutamakan pembudayaan dan pemberdayaan peserta didik sebagai pembelajar sepanjang hayat, 10) Pembelajaran yang menerapkan nilai-nilai dengan memberi keteladanan (Ing Ngarso Sung Tulodo), membangun kemauan (Ing Madyo Mangun Karso), dan mengembangkan kreativitas peserta didik dalam proses pembelajaran (Tut Wuri Handayani), 11) Pembelajaran yang berlangsung di rumah, di sekolah, dan di masyarakat, 12) Pemanfaatan teknologi informasi dan komunikasi untuk meningkatkan efisiensi dan efektivitas pembelajaran, 13) Pengakuan atas perbedaan individualdan latar belakang budaya peserta didik, 14) Suasana belajar menyenangkan dan menantang.

\section{Metode Penelitian}

Penelitian ini dilaksanakan di Fakultas Keguruan dan Ilmu Pendidikan Universitas HKBP Nommensen. Subjek dalam penelitian ini adalah seluruh mahamahasiswa program studi pendidikan matematika FKIP UHN Medan yang mengikuti mata kuliah Analisis Rill 1, yang terdiri dari 3 kelas. Yang menjadi objek dalam penelitian ini adalah mahasiswa yang mengalami perlakuan dengan model pembelajaran pencapaian konsep dengan pendekatan ilmiah terhadap ketuntasan representatif mahasiswa. Adapun waktu pelaksanaan penelitian ini adalah semester ganjil tahun pelajaran 2019/2020.

Penelitian ini termasuk penelitian jenis eksperimental bersifat quasieksperimen yang bertujuan untuk mengetahui persentasi ketuntasan kemampuan representatif mahasiswa prodi pendidikan matematika FKIP UHN yang diajarkan dengan desain model pembelajaran pencapaian konsep dengan pendekatan ilmiah. Hasil penelitian yang dihasilkan nanti bersifat deskribtif yang akan mendeskribsikan persentase ketuntasan dan pola jawaban kemampuan representatif mahasiswa prodi pendidikan matematika FKIP UHN yang diajarkan dengan desain model pembelajaran pencapaian konsep dengan pendekatan ilmiah.

Penelitian ini melibatkan satu kelas yang diajarkan dengan model pembelajaran pencapaian konsep dengan pendekatan ilmiah terhadap kemampuan representatif matematis mahasiswa prodi pendidikan matematika FKIP UHN. Rancangan penelitian yang digunakan adalah One- shot case study adalah sekolompok sampel dikenai perlakuan tertentu (variabel bebas) kemudian dilakukan pengukuran terhadap variabel tersebut. Desain penelitian ini dapat digambarkan sebagai berikut :

Tabel 1. Tabel One- shot case study

\begin{tabular}{|l|c|c|c|c|}
\hline Kelompok & Treatment & Test-1 & Treatment & Test-2 \\
\hline Eksperimen & $\mathbf{X}$ & $\mathbf{O}_{1}$ & $\mathrm{X}$ & $\mathbf{O}_{2}$ \\
\hline
\end{tabular}


Keterangan :

$\mathrm{X}=$ perlakuan dengan model pencapaian konsep dengan pendekatan ilmiah

$\mathrm{O}=$ Tes kemampuan representatif.

Sebagai upaya untuk mendapatkan data dan informasi yang lengkap mengenai hal-hal yang ingin dikaji melalui penelitian ini, maka dibuatlah seperangkat instrumen. Instrumen yang akan digunakan pada penelitian ini adalah: 1) Tes. Tes berisikan serentetan pertanyaan atau latihan serta alat lain yang digunakan untuk mengukur kemampuan siswa dalam memecahkan masalah matematika dalam menyelesaikan soal. Bentuk test yang diberikan adalah essay (tes isian). Post Test ini digunakan untuk mengetahui ketuntasan belajar yang dilihat dari daya serap materi pelajaran. 2) Observasi. Observasi pengamatan yang dilakukan untuk mengamati keseluruhan aktivitas yang terjadi selama proses pembelajaran berlangsung. Faktor-faktor yang diamati adalah hal-hal yang berkaitan dengan pelaksanaan model pembelajaran pencapaian konsep yaitu kemampuan guru mengajar menggunakan model pembelajaran yang ditinjau dari kesesuaian materi dengan model, penyampaian materi, komunikasi guru dengan siswa.

Untuk mempermudah pelaksanaan penelitian, maka perlu dirancang suatu prosedur penelitian yang sistematis. Prosedur tersebut merupakan arahan bagi peneliti dalam melaksanakan penelitian dari awal sampai akhir. Dalam penelitian ini peneliti membagi prosedur penelitian menjadi tiga tahap, yaitu: 1) Persiapan Penelitian. Pada tahap persiapan ini dilakukan langkah-langkah sebagai berikut: a) Mengidentifikasi permasalahan; b) Membuat proposal penelitian; c) Seminar proposal penelitian; d) Mengurus perizinan dengan pihak terkait; e) Membuat instrumen penelitian; f) Melakukan uji coba instrumen; g) Merevisi instrumen penelitian. 2) Pelaksanaan Penelitian. Pada tahap pelaksanaan ini dilakukan langkah-langkah sebagai berikut: a) Memilih sampel yang akan digunakan dalam penelitian; b) Melaksanakan pembelajaran matematika dengan menggunakan model pembelajaran problem based instruction menggunakan LKS; c) Melaksanakan observasi terhadap kemampuan guru megajar dengan model pembelajaran dan rentang waktu; d) Memberikan post-tes. 3) Analisis Data. Taknik analisis data hasil dalam penelitian ini adalah teknik Analisis Deskriptif. Menganalisis data secara deskriptif dilakukan dengan menghitung persentase pencapaian minat belajar peserta didik.

Teknik analisis data yang digunakan dalam penelitian ini adalah teknik analisis data deskriptif, yaitu dengan memaparkan dan menyajikan data hasil post tes dengan tampilan persentase ketuntasan. Data yang digunakan untuk mengetahui pencapaian kemampuan representatif adalah data hasil tes yang dirancang sesuai dengan indikator kemampuan representatif matematis. Adapun yang akan dideskripsikan dalam penelitian ini adalah pencapaian kemampuan representatif mahasiswa mahasiswa prodi pendidikan matematika FKIP UHN yang diajarkan dengan model pembelajaran pencapaian konsep dengan pendekatan ilmiah kemampuan representatif mahasiswa yang diajarkan dengan model pembelajaran pencapaian konsep dengan pendekatan ilmiah.

Indikator keberhasilan dalam penelitian ini adalah ketuntasan belajar dilihat dari: 1) Daya serap perseorangan. Seorang siswa disebut telah tuntas dalam belajar bila ia telah mencapai skor $\geq 70 \%$ atau nilai $\geq 70$. Dilihat dari hasil belajar siswa. 2) Daya serap klasikal. Suatu kelas dinyatakan telah tuntas belajar apabila kelas tersebut telah terdapat $\geq 80 \%$ siswa yang telah mencapai nilai $\geq 70$. Dilihat dari hasil belajar kelas.

\section{Hasil Penelitian dan Pembahasa}


Telah dijelaskan sebelumnyabahwa tujuan penelitian ini adalah untuk mengetahui persentasi ketuntasan kemampuan representatif mahasiswa yang diajarkan dengan desain model pembelajaran pencapaian konsep dengan pendekatan ilmiah. Dari hasil penelitan diperoleh bahwa desain model yang dibuat sudah sangat baik karena: 1) aktivitas mengajar dosen telah sesuai dengan model pembelajaran pencapaian konsep dengan pendekatan ilmiah karena total rerata hasil pengamatan dari observer pada semua aspek dan indikator model adalah 4,55 yang artinya kemampuan mengajar guru menggunakan model "Sangat Baik". 2) aktivitas aktif siswa juga telah sesuai dengan la ngkah model pembelajaran pencapaian konsep dengan pendekatan ilmiah karena nilai rerata aktivitas aktif siswa dari hasil observasi adalah 4,51 yang artinya aktivitas aktif siswa berada pada kategori "Sang Baik".

Selanjutnya kita akan melihat pencapaian ketuntasan kemampuan representatif mahasiswa yang mengikuti matakuliah analisis riel 1. Untuk mengetahui lebih jelasnya perhatikan tabel 2 berikut.

Tabel 2. Pencapaian Ketuntasan Kemampuan Representatif Mahasiswa

\begin{tabular}{|c|c|c|c|}
\hline Keterangan & Jumlah & $\begin{array}{c}\text { Persentase } \\
(\%)\end{array}$ & Keterangan \\
\hline Tuntas & 95 & 86,36 & \multirow{2}{*}{$\begin{array}{c}\text { Tuntas secara } \\
\text { klasikal }\end{array}$} \\
\hline Tak Tuntas & 25 & 13,64 & \\
\hline Total Siswa & \multicolumn{2}{|c|}{110} & \\
\hline Rata-rata Nilai & \multicolumn{2}{|c|}{76,513} & Tuntas \\
\hline
\end{tabular}

Dari tabel 4.5. terlihat bahwa sebanyak 95 orang dari 110 orang atau sekita 86,36\% mahasiswa telah mencapai nilai ketuntasan minimal sedangkan 25 orang lagi atau sekitar $13,64 \%$ mahasiswa belum mencapai nilai $\geq 75$. Hal ini menunjukkan bahwa pencapaian ketuntasan kemampuan representatif mahasiswa prodi pendidikan matematika yang mengikuti matakuliah analisis riel 1 tahun akademik 2019/2020 telah tuntas secara klasikal.

Dari tabel 4.5. di atas juga dapat kita lihat bahwa nilai rata-rata total yang dicapai oleh mahasiswa yang mengikuti matakuliah analisis riel 1 adalah sebesar 76,513. Hal ini menunjukkan bahwa nilai rata-rata yang dicapai seluruh siswa yang mengikuti matakuliah analisis riel 1 telah mencapai kriteria ketuntasan minimal $\geq 75$, hal ini menunjkukkan bahwa rerata pencapaian kemampuan representatif mahasiswa yang mengikuti matakuliah analisis riel 1 telah tuntas secara klasikal

\section{Kesimpulan}

Kesimpulkan dari penelitian ini adalah: 1) Desain model pembelajaran pencapaian konsep dengan pendekatan ilmiah terhadap kemampuan representatif yang telah dirancang sudah sangat baik karena aktivitas mengajar dosen dari observer pada semua aspek dan indikator model adalah 4,55 dan aktivitas aktif mahasiswa dari hasil observasi adalah 4,51 yang artinya aktivitas aktif mahasiswa berada pada kategori "Sang Baik". 2) pencapaian ketuntasan kemampuan representatif mahasiswa prodi pendidikan matematika yang mengikuti matakuliah analisis riel 1 tahun akademik 2019/2020 telah tuntas secara klasikal karena 95 orang dari 110 orang atau sekita 86,36\% mahasiswa telah mencapai nilai ketuntasan minimal $\geq 75$.

\section{Referensi}

Abrahamson, D. (2006). Mathematical representations as conceptual composites: Implications for design. Paper presented at the 28th annual meeting of the North American Chapter of the International Group for the Psychology of Mathematics Education, Merida, Mexico. 
Depdiknas. 2007. Permendiknas Nomor 22 Tahun 2006 Tentang Standar Isi Sekolah Dasar. Jakarta: Depdiknas

Dundar, S. 2015. Mathematics Teacher-Candidates' Performance in Solving Problems with Different Representation Styles: The Trigonometry Example. Eurasia Journal of Mathematics, Science \& Technology Education. Vol. 11(6). pp: 1379-1397.

Dundar, A., Hossler, D., Shapiro, D., Chen, J., Martin, S., Torres, V., Zerquera, D., \& Ziskin, M. (2015). National Postsecondary Enrollment Trends: Before, During, and After the Great Recession (Signature Report No.1). Herndon, VA: National Student Clearinghouse Research Center.

Hutagaol, Kartini. 2013. Pembelajaran Kontekstual Untuk Meningkatkan Kemampuan Representasi Matematis Siswa Sekolah Menengah Pertama. Diakses pada http://ejournal.stkipsiliwangi.ac.id/index.php/infinity/article/view/27/26

Indah, Widiati. 2015. Mengembangkan kemampuan representasi matematis siswa sekolah menengah pertama melalui pembelajaran kontekstual. JPMIPA: 20(2). http://journal.fpmipa.upi.edu/index.php/jpmipa/article/view/571

Joyce, Bruce, (2009), Models Of Teaching (Model-Model Pengajaran), Yokyakarta. Pustaka Pelajar

Kaput, J. (1991). Notations and representations as mediators of constructive processes. In E. v.Glasersfeld (Ed.), Constructivism and mathematics education, (pp. 53-74). Dordrecht,Netherlands: Kluwer.

Mulligan \& Mitchelmore. 2009. Awareness of Pattern and Structure in Early Mathematical Development. Mathematics Education Research Journal: 21(2). https://link.springer.com/article/10.1007/BF03217544

Nainggolan, Sintong. 2015. Upaya Meningkatkan Reativitas Berpikir Matematis Melalui Model Pembelajaran Pencapaian Konsep Pada Siswa Kelas VII SMP Negeri 1 Bilah Barat. Medan: JSP 2(1):(65-76). https://jsp.uhn.ac.id

NCTM. (1989). Curriculum and Evaluation Standards for School Mathematics. Reston, VA : NCTM

Panasuk, R. 2011. Preferred Representation of Middle School Algebra Students When Solving Problem. The Mathematics Educator, Vol 13(1), 32-52.

Siahaan, Friska. 2018. Penggunaan Perangkat Pembelajaran Berdasarkan Teori APOS Untuk Meningkatkan Kualitas Perkuliahan Teori Bilangan. JSP: 5(1). https://jsp.uhn.ac.id

Situmorang, Adi S. 2019. Desain Model Pencapaian Konsep Terhadap Minat Belajar Mahasiswa FKIP UHN. Jurnal Penelitian Bidang Pendidikan Unimed: 25(1) https://jurnal.unimed.ac.id/2012/index.php/penelitian/issue/archive 